\title{
Batı Resminde “Doğu” İmgesinin Oluşmasına Aracılık Eden Kadın Temsilleri
}

Dr. Öğr. Üyesi Meryem Uzunoğlu

\section{Özet}

Oryantalist resim repertuarı içinde Batılılar için büyülü bir gizemi olan harem yaşantısı önemli bir yer tutmaktadır. Bu resimlerde doğulu bir dekor içinde ve doğulu kostümler giymiş olan egzotik güzellerin biçimsel kökenleri

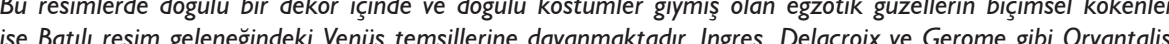
ise Bathi sanatç gostermek is olduks usg


sorgulamaya başlayan Bati da Doğg ya olan oryantalist igi azalmiş ve harem sahneleri populenligini yitirmiştir

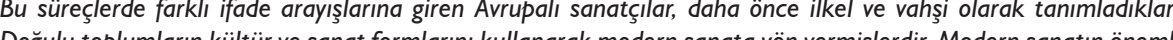

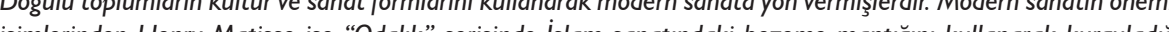
isimlerinden Henry Matisse ise "Odalk" serisinde islam sanatındaki bezeme mantiğinı kullanarak kurguladı̆ resim mekânında bu Doğulu "tutsak" kadını, merkezi bir motife donusşturmek suretiyle yalnızca biçimsel bir öge konumuna indirgemiştir. Boylece Oryantalist soylem içerisinde "Dogu" imgesinin kurulmasına ve yayginlaşmasıina aracılık eden kadın figürünün ifade ettiği anlamın içi boşaltılmıştır. Bu çalışmada oryantalizmin tanımı yapılacak; tarihsel süreçte Doğu-Batı ilişkisinin kültür ürünlerindeki yansımalarına değinilecek; öteki üzerinden kendin tanımlama biçimi olarak oryantalist resimlerdeki ideolojik bağlam üzerinde durulacak ve oryantalist resim geleneği içinde kadın temsilleri aracilığı ile Doğu imgesinin nasıl şekillendiği incelenecektir.

Anahtar Kelimeler: Oryantalizm, Doğu İmgesi, Harem, Odalık, Venüs Şablonu

FEMALE REPRESENTATIONS MEDIATING THE FORMATION OF "EAST" IMAGERY IN WESTERN PAINTING

\section{Abstract}

The harem experience, which is a magical mystery for the Westerners in the Orientalist painting repertoire, has an important place. In this paintings, the formal origins of exotic beauties, in an oriental décor and dressed in oriental costumes, are based on Venus representations in the Western painting tradition. The "captive" women in the harem stages, described by Orientalist artists Ingres. Delacroix and Gerome are well suited to show the in the harem stages, described by Orientalist artists Ingres, Delacroix and Gerome are well suited to show the subconscious, will both legitimize his action and will be his power. Towards the end of the nineteenth century Orientalist interest in East decreased in the West, which began to question its civilization, and the popularity of Orientalist interest in East decreased in the West, which began to question its civilization, and the popularity of
the harem scenes was lost. In this process, European artists who have been searching for different expressions the harem scenes was lost. In this process, European artists who have been searching for different expressions have directed modern art by using the culture and art forms of Oriental societies they have described as primitive and savage. Henry Matisse, one of the most important figures of modern art, has reduced this Oriental "captive" woman into a mere formative element by transforming it into a central motif in the painting place, which he created using embellishment logic in Islamic art, in the Odalisque series. Thus, in the Orientalist discourse, the meaning expressed by the female figurine who mediates the establishment and spread of the "East" image has been evacuated. In this study Orientalism will be defined; in the historical process, the reflections of the EastWest relationship in cultural products will be referred to; it will focus on the ideological context in Orientalis paintings as a way of defining itself through the other; and through the representation of women in Orientalist painting tradition it will examine how it shaped the image of the East.

Keywords: Prototype Design, Interface Design, Prototype Techniques, Interaction Design

Yrd. Doç. Meryem Uzunoğlu, Uludağ Üniversitesi, Güzel Sanatlar Fakültesi, Resim Bölümü, Burs E-posta: meryemuzunoglu@uludag.edu.tr 
Bu araştırmanın bağlamını oluşturan "Oryantalizm" kavramı Batı dillerinde güneşin doğduğu yer anlamına gelen orient kelimesinden türetilmiştir. 19 yüzyıl ortalarında Fransız yazar Teophile Gautier'nin yazılarında Doğu coğrafyalarını konu alan bir resim türünü kavramsallaştırmak için kullanılmaya başlayan Oryantalizm, zamanla Batı'nın Kuzey Afrika kıyılarından Orta Asya steplerine tüm Osmanlı İmparatorluğu topraklarını, zaman zaman da Hindistan yarımadasını içine alan İslam dünyası karşııındaki doktrinleri tanımlayan genel bir kavram olarak benimsenmiştir (Germaner, İnankur, 1989: 9). Oryantalizm, Doğu insanlarının dinlerini, dillerini, kültürlerini ve tarihlerini inceleyen Batı kökenli ve Batı merkezli araştırma alanlarının tümünü kapsamaktadır (Çırakman, 2003: 119). Edward Said 1978 yılında yayınlanan kitabında oryantalizmi, Batı'nın kendi kimliğini ifade etmesinin, kendisini tanımlayıp eylemini meşrulaştırmasının dolayımlı, ideolojik ve kültürel yolu olarak tanımlamıştır (Ulluç, Soydan, 2007: 37).

Kendini tanımlamak için "ötekine" duyulan ihtiyaç, insanlık tarihi kadar eski bir olgudur. Üstelik sadece Batı'lı aklın bir yönelimi olduğunu iddia etmek mümkün değildir. Hayatı rasyonalize etme çabası olarak da anlaşılabilecek bu durum Batı'da zamanla sistematik hale gelmiş ve Doğu ile Batı arasında gerilimli bir ilişkinin oluşmasına neden olmuştur. Bu iki dünya arasında daima var olan kültürel alışverişi siyasi ihtilaflar ve savaşlar kadar ticar ilişkiler de körüklemiş; "öteki" etrafında oluşturulan mitler, edebi eserlere olduğu kadar ressamların yapıtlarına da konu olmuştur. 72. Venedik dükü Giovanni Mocenigo ressam Gentile Bellini'yi Fatih'in tablosunu yapmak üzere İstanbul'a göndermiş; Costanza De Ferrara 1481'de Fatih'in madalyonunu yapmış; Titian ise 1530 yılında, Kapitülasyonlar olarak bilinen Osmanlı-Fransız ittifakını başlatan Kanuni Sultan Süleyman ile I. François'nın birlikte portrelerini boyamıştır. Rembrandt ve Hans Holbein'in eserlerinde de Doğu'ya ilişkin imgeler bulunmaktadır. 1558 yılında yapılmış Melchior Lorich'e ait olduğu söylenen çizimlerde ise bir haremde müzik yapan ve dans eden bir kadın görülmektedir (Denny, 1983: 271).

Gerek Doğu gerekse Batı sanatında önceden beri yabancı kültürlere ait olumsuz, komik, kötü yada çirkin imgelere rastlamak da mümkündür. Ancak Denny, Batılı sanatçılar için Doğu imgesinin farklı kültürlere duyulan önyargılardan daha karmaşık sebeplere bağlı olabileceğini ifade etmektedir (1983: 266). Oryantalist sanat kapsamına giren eserlerdeki ırkçı, cinsiyetçi ve kültürel önyargıları barındıran imajlar, 19. yüzyıldan itibaren sömürgeci söylemin bir parçası haline gelmiştir. Fakat Oryantalizm sadece Doğu üzerine bir söylem olarak anlaşılmamalıdır. Asıl tuzak "Doğu" diye bir başka yer üzerine bir söylemin ortaya çıkmıs olmasıdır. Foucault'cu bir yaklaşımla Oryantalist kurguyu bilgi-iktidar ilişkisi üzerine yapılanmış bir aygıt olarak ele alan Said, Doğu'nun ve Doğulu'nun bilgisini üretmeksizin Batının sömürgeci, emperyalist bir güce dönüşemeyeceğini iddia etmektedir. Öte yandan bu bilgi, emperyalist ilerlemenin sağladığı olanaklarla toplumsal bağlamda tekrar tekrar üretilmiştir. Edebi, iktisadi, akademik, ahlaksal vb. kurumlar aracilığıyla oluşturulan söylemde "Doğu" farklı bi yer olarak işaretlenmiştir. Bu söylem içinde "farkı" olanı damgalayarak kendinin zıddı olan bir "öteki" üreten Batı, yerleştiği merkezi konumun üstünü örterek kendini "evrensel" bir bilgi öznesi kılmışır. Böyle bir bilgi toplumsal katmanlara nüfuz edip bir boşluğu doldurduktan ve yansızlığ kesinleştikten sonra söylemsel mekana da hakim olmuştur (Keyman, 1999: 31-33). Bu nedenle Doğu ile ilgili verilen beyanatlar, takınılan tavırlar ve yapılan benzetmeler, bir hükmetme şekli, üstünlük sürdürme taktiği ve Doğu üzerinde otorite kurma çabası olarak yorumlanmaktadır (Said 1998: 14). Doğu etrafında oluşturulan tüm klişeler, Batı'nın Kuzey Afrika ve Ortadoğu topraklarına yönelik sömürgeci eylemlerini haklı gösterip meşrulaştırma çabasının araçları olarak görülebilir (Güçsav, 2012:12). Öte yandan oryantalist sanatçıların bu ideolojinin taşıyıcııı̆ı̆ını bilinçli bir şekilde yaptıklarını söylemek herzaman mümkün olmayabilir. Batının ürettiği bilginin evrensel bir bilgi olduğu ön kabulü ile kendilerini merkezi bir yere konumlandıran sanatçılar için Doğu zaten farkıdır ve doğal olarak ötekidir.

Oryantalist resim repertuvarı içinde İslam dinine ait ritüeller, gündelik yaşam sahneleri ve Batılılar için büyülü bir gizemi olan harem yaşantısı yer almaktadır. Walter B. Denny'ye göre oryantal imgeler, Oryantalist sanat üç ana başlıkta incelememizi gerektirmektedir (1983: 266). Bunlardan biri Belgesel Oryantalizm'dir; bu çerçevede olgular, kişiler ve olaylar gerçekte olduğu gibi ele alınır. İlgi genellikle politik figürlerde özellikle de padişahlardadır. Kısmen dini pratikler, dügünler ve kutlamalar da eserlere konu olmuştur. Politik Oryantalizm'de Doğu ve Doğu'yla ilgili imgeler, dini ve politik mesajlar vermek üzere kullanılmıştır. Denny, bu mesajların genellikle İslam karşıtı olduğunu dile getirmektedir. Egzotik Oryantalizm'de ise sanatçılar Doğu'ya ait imgeleri, duyguları ortaya çıkarmak ve konuları canlandırmak için kullanmışlardır. Oryantalist bütünün en dikkat çekici bölümü olan Egzotizm'in tarihsel gerçekliğe, kadın duyarlığına, iyi beğeni ölçütlerine, ırksal eşitlik ve kültürel hoşgörü kavramlarına karşı bir saldırı içerdiği söylenebilir (Denny, 1983: 266).

Doğulu bir dekor içinde ve Doğu tarzı kostümleri ile egzotik olanı temsil eden harem kadınının biçimsel kökenleri Batılı nü resim geleneğindeki Venüs temsillerine dayanmaktadır. Esasen Roma mitolojisindeki aşk ve güzellik tanrıçası Venüs, Erken Rönesans'tan itibaren Batı resmine konu olmuştur. Giorgione'nin "Uyuyan Venüs" isimli eserinden sonra çoğunlukla 
resim düzlemine paralel bir döşek üzerinde tembelce uzanan nü figürlerin çeşitli varyasyonları yapılmıştır. Zamanın güzellik anlayışına uygun olarak betimlenen bu kadınlar, zengin kumaş kıvrımları arasında yatarlarken, bir elleri başlarının arkasına uzanmış diğer elleri ise cinsel uzuvlarını örtecek şekilde konumlandırılmışlardır. Genellikle, yüzleri izleyiciye dönük olan bu kadınlar izlendiklerinin farkındadırlar. Bazen dayandıkları yüksek yastıklar, bazen de başlarının arkasına uzanan kolları nedeniyle bedenleri hafifçe yukarıya kalkarak resim düzleminde diyagonal bir hareket oluştururlar. Çoğunlukla iç mekanda betimlenseler de arka plandaki bir pencere, kemer ya da kapı gibi bir açıklıktan görünen doğa manzarası, espası ufuk çizgisine değin uzatır. Bu resimlerde Venüs'e bazen Cupid, bazen Ares, bazen Satir eşlik etmekte; bazen de hepsi birlikte betimlenmektedirler. Titian, Velazquez, Rubens, Goya, Cabanel ve Manet gibi belli başlı sanatçıların da katkısıyla yüzyıllar içinde oluşan bu Venüs şablonu, çıplaklığın ayıp ve günah sayıldığı erkek egemen Batı kültüründe, nü betimlere toplumsal bir meşruiyet kazandırmışıı. Erkek sanatçılar tarafından erkek izleyiciler için üretilen Venüs betimlemeleri yakın döneme kadar yaşamın içindeki çıplaktan farklı olarak konumlandırılmıştır.

Ondokuzuncu yüzyıldan itibaren Venüs şablonu Oryantalist gelenek tarafından devralınmıştır. Esasen Batı kültüründe yüzyıllar içinde çok iyi tanımlanmış olan bu şablon, Doğu'yu tensel şehvet düşkünü olarak göstermek için çok uygundur... Ondokuzuncu yüzyılda sömürgeci niyetlerle Doğu'ya yönelen Batı, eylemini meşrulaştırmak ve haklı göstermek için bilim ve edebiyatı olduğu kadar resim sanatını da araçsallaştırmış; ve oluşturduğu "öteki" söyleminin toplumsal yapının tüm katmanlarına nüfuz etmesini sağlamıştır. Oryantalist resimlerde kan ve kılıçla simgelenen Doğu, barbar ve despotik bir toplum olarak Batı'nın fethetmesi ve medeniyet götürmesi gereken bir yer olarak işaretlenmiştir.

Doğu-İslam coğrafyasının sömürgeleştirilme sürecinde, "harem"in kalın duvarları arasında yaşayan ya da "peçe" nin ardında gizlenen kadın, Batıı erkek özne için her daim gizemini korumuştur. Doğulu kadının bu görünmezliği ve dolayısıyla ulaşılmazlığı fethettiği toprağı kontrol etme ve ona hakim olma arzusunda olan sömürgeci öznenin merakının fanteziye dönüşmesine neden olmuştur. Bilinçdışının devreye girdiği karmaşık bir sürece işaret eden bu durum, Denny'nin Egzotik Oryantalizm başıı̆ı altında ele aldığı eserlerin arka planına açıkık getirmektedir. Odalık temasının işlendiği oryantalist eserlerde cinsel obje konumuna indirgenen kadınlar, sınırsız bir dişilik ve şehvet sunarlar ve hakimiyet altına girmeye istekli görünürler. Doğu ile ilgili bu cinsel imgelem, Batı'nın sömürgeci çıkar ve arzularından bağımsız değildir. Bu resimlerde basit, sefil ve boyun eğen olarak sunulan kadınlar, içinde yaşadıkları İslam coğrafyasını da simgelemektedirler. Dolayısıyla harem temasını işleyen resimlerde, kendini idare etmekten aciz olan Doğu'yu fethederek hakimiyet altına alma ve yönetme arzusunun meşruiyeti, örtülü bir şekilde ifade edilmektedir.

Ondokuzuncu yüzyılın ilk yıllarında Gros ve Girodet'nin, Napolyon için gerçekleştirdikleri savaş resimleri ile başlayan Fransa'daki Doğu ilgisi, kısa sürede romantizmin etkisi ile Oryantalizm modasına dönüşmüştür. Bu süreçte gerçekleştirilen resimler çoğunlukla imgeseldir; sanatçılar Doğu'ya yapılan seyahatlerde çekilen fotoğraflardan yola çıkarak Fransa'da bulabildikleri egzotik eşyalarla oluşturdukları kompozisyonları lokal renkler kullanarak boyamışlardır. Bonington ve Ingres gibi büyük ustalar aslında Doğu'ya hiç gitmemişlerdir. Oryantalist sanatçıların en önemli esin ve bilgi kaynağı edebi yapıtlar ve gezi anıları olmuştur. Delacroix ise Doğu'ya yalnızca bir kez kısa bir seyahat yapmıştır. Sanatçı, "Sakız Adası Katliamı" ve "Sardanapalus'ın Ölümü" adlı eserlerini Fas ziyaretinden önce gerçekleştirmiştir. Ondokuzuncu yüzyılın ikinci yarısına gelindiğinde gizemli Doğu düşüncesi, artık sanatçılara egzotik resimler boyamak için bir bahane oluşturmaya başlamışır (Needham, 1982: 339).

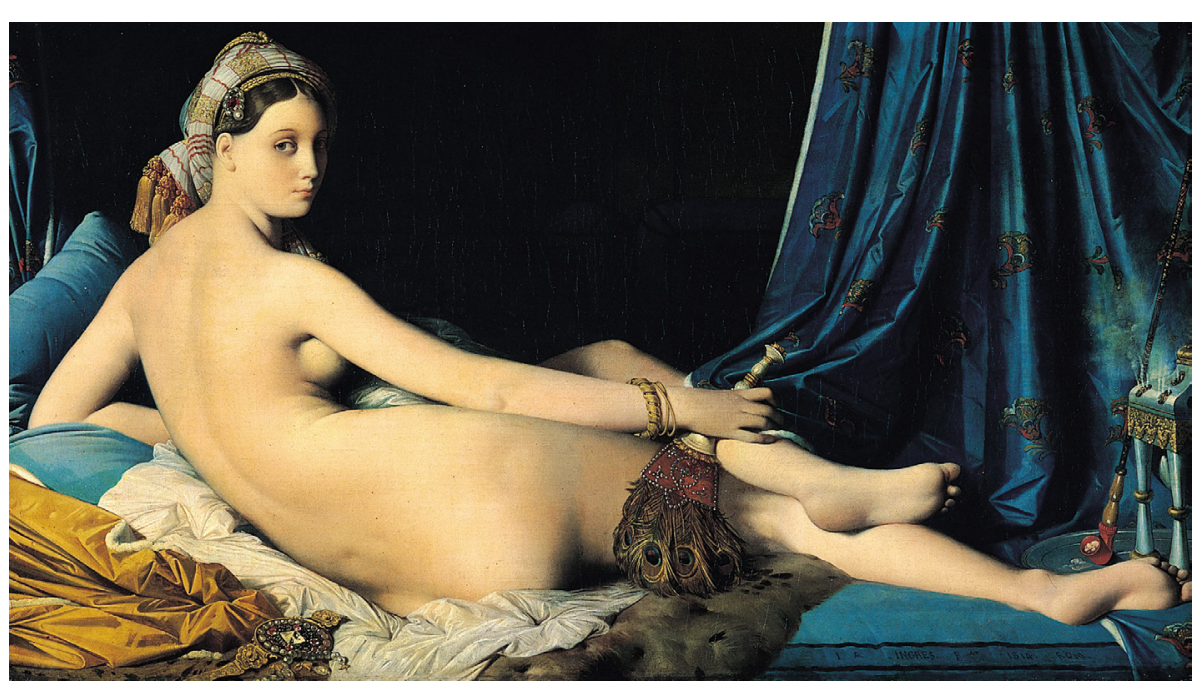

Resim I. Jean Dominique Ingres, Büyük Odalık, 1814 , tüyb. $162 \times 91 \mathrm{~cm}$.

Sanat yaşamı boyunca Doğu ile ilgili pek çok eser üreten Jean Dominique Ingres'ın Doğu hakkındaki bilgisi, Avrupa edebiyatının efsanevi anlatımları ve Lady Mary Montagu'nün 1763'te yayınlanan mektuplarının da içinde olduğu seyahat notlarına dayanmaktadır (Güçsav, 2012: 62). Sanatçının 
1814'te boyadığı "Büyük Odalık" isimli eserde resim düzlemine paralel olarak konumlandırılmış bir yatak üzerinde uzanan bir nü betimlenmiştir. Kadrajın neredeyse tamamını kaplayan bu çıplak kadın arkadan gösterilmiş olmasına rağmen yüzünü izleyiciye dönmüştür. Sol dirseğinden destek alarak arkasında duran büyük yastığa dayanmak suretiyle gövdesini yukarıya doğru kaldırması yatay kompozisyonda diyagonal bir hattın oluşmasına neden olmuştur. Sağ elinde tavus kuşu tüylerinden yapılmış bir yelpaze tutmaktadır. Ayakucundaki gümüş tepsinin üzerinde uzun saplı bir pipo ile buhurdanlık durmaktadır. Buhurdanlıktan çıkan duman odada bir tütsünün yakıldığını düšündürür. Genç kadının muhtemelen resim zamanından biraz önce üzerinden çıkarıp yatağın üstüne bıraktığı kıyafetler ile kürkün bir kısmı görülmektedir. Kumaş yığının arasında değerli taşlarla süslü bir altın kemer dikkati çekmektedir. Sağ taraftan kadraja giren mavi renkli ağır perdenin ucunu sağ eliyle zarifçe kavramış olan çıplağın izleyiciye yönelen bakışları bu mahrem anın biraz sonra sona ereceğini ima eder.

Tüm tenselliğine rağmen son derece zarif bir görüntüsü olan figürün başındaki değerli taşlarla süslenmiş türbanı ve etrafındaki Doğulu nesneler, yapıtı oryantalist bütünün içine dâhil eder. Oysaki Ingres'ın eseri biçimsel olarak, uzanan Venüs geleneğini takip etmektedir. Sanatçı Velazquez'in Aynalı Venüs'ünde olduğu gibi modelini sırtından göstermek suretiyle izleyici ile arasına bir mesafe koymuştur. Öte yandan Ingres burada figürün anatomisini alabildiğine zorlamıştır. Modelin büyük bir yay çizen sırtı olağandan çok daha uzundur; boyun hiç kasılmadan başın o denli büyük bir açı ile çevrilmesi ise imkânsızdır. Sağ kol, sola nazaran oldukça uzundur. Diğerinden daha uzun olan sol bacağın kalça ile birleşmesi de imkân dâhilinde görünmemektedir. Dahası çıplağın ne yüzünde ne de bedeninde zorlandığını ya da kasıldığını gösteren en ufak bir işaret bulunmamaktadır. Tüm bu detaylar, onun sadece tenden ibaret olduğunu, bedeninde hiç kemik bulunmadığını düşündürür.

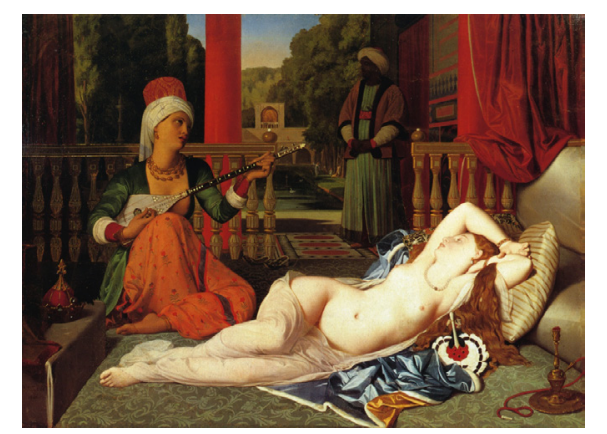

Resim 2. Jean Auguste Dominique Ingres, Köle ve Odalık, 1842, tüyb, $76 \times 105 \mathrm{~cm}$.
Ingres 1842 tarihli "Köle ve Odalık" adlı eserinde uzanan Venüs geleneğini Doğulu "öteki" olarak modern bir bağlama taşımıştır. Resmin ön planında soldan sağa doğru bir diyagonal oluşturacak şekilde uzanan çıplak kadın figürünün Giorgione ve Tiziano'nun Venüs figürleri ile bağları oldukça açıktır. Ancak "Büyük Odalık" tan yaklaşık 28 yıl sonra gerçekleştirdiği bu eserde odalığın çıplaklığını açık seçik sunmayı yeğlemiştir. Genç kadının beyaz teni ve kızıl saçları onun Batılı olduğunu ima etmektedir. Biraz arkada oturmuş müzik aleti çalan kadın ve ahşap korkulukların gerisinde ayakta duran siyahi erkek figürünün giysileri mekânın bir harem olduğunu düşündürürken ön plana yerleştirilmiş nargile, biraz arkada sağda duran ibrik ve Türk halıları bu fikri desteklemektedir. Kırmızı sütunun arkasından ufuk çizgisine doğru uzanan dış mekândaki atmosferik etkiler Ortadoğu'nun çöl ikliminden ziyade Kuzey ülkelerinin ışığını yansıtmaktadır. Bahçedeki havuzun kenarında betimlenmiş figürlerin neşeli dinamizmi ise iç mekândaki mahrem sessizlikle karssıtık oluşturur. İili karşıtlıkların şekillendirdiği bu kurgusal gerçekliğin aslında Ingres'ın fantezi dünyasının bir ürünü olduğu ifade edilebilir. Böylece Batılı erkek öznenin kurduğu erotik fanteziler, uzaktaki gizemli Doğu imgesi üzerine giydirilerek meşrulaştırılmıştır.

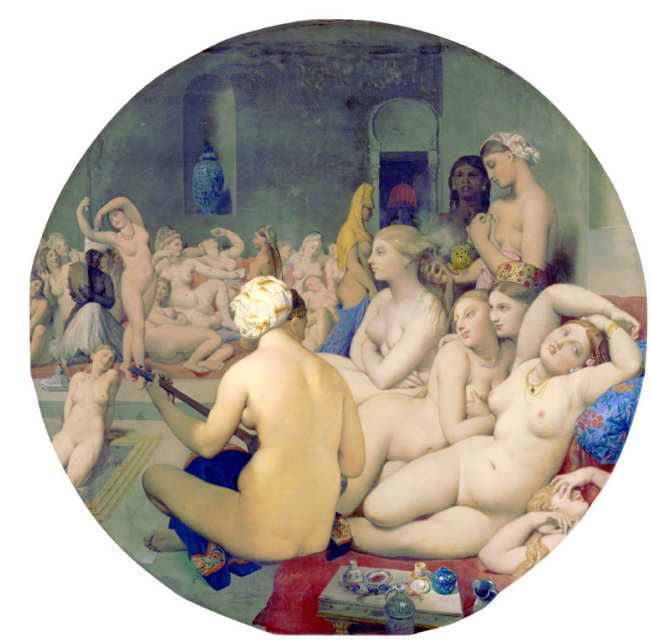

Resim 3. Jean Auguste Dominique Ingres, Türk Hamamı, I862, tüyb, çap: $108 \mathrm{~cm}$

SIngres'ın Türk Hamamı (1862) adlı eseri, yaklaşık bir buçuk asır önce eşi Fransa'nın İstanbul Büyükelçisi olan Lady Mary Wortley Montagu'nün yazdığı bir mektupta tasvir ettiği hamam sahnesinden yola çıkarak yaptığı bilinmektedir. Resmin ön planında hafif solda betimlenmiş olan türbanlı figürü, sanatçı daha önce "Valpinçonlu Yıkanan" (1808) adlı eserinde de kullanmıştır. İzleyiciye sırtı dönük olduğu halde yere bağdaş kurarak otur- 
muş olan bu kadın ud çalmaktadır. Kompozisyonun içine sıkıştırılmış yirmi yedi adet kadın figürünün çıplak oluşu ve geriye doğru gidildikçe atmosferin buğulu bir görünüme bürünmesi, sol taraftan kadraja giren havuz ve karşı duvardaki nişin içine yerleştirilmiş çini vazo gibi detaylar, mekânın Türk hamamı olduğunu düşündürmektedir. Öte yandan bembeyaz tenleri, iri göğüsleri ve dolgun vücutlarıyla erotik pozlar vermiş olan bu kadınların pek çoğu Ingres'ın diğer resimlerinden devşirilmiştir. Bir eğlence anı betimlenmiş olmasına rağmen huzursuz bir durağanlık resmin tüm atmosferine yayılmış gibidir. Richard Leppert, resmin ne Türk hamamı, ne Türk kültürü ne de Türk tarihi ile bir ilgisi bulunmadığını ifade etmektedir. Ona göre Ingres'ın "Türk Hamamı" adlı eseri, Ortadoğu'yu yasak cinsellik ve ilkellikle özdeşleştirip oryantalizmin kaynağı olarak sunmaya çalışan bütün o Bat fantezilerinin bir araya geldiği bir kurgudur (2009: 314).

1820 'lerin başlarından itibaren oryantalist nitelikli temalarla ilgilenmeye başlayan Eugene Delacroix'nın Batı'daki edebi ve görsel betimlerden, özellikle de Ingres'ın 1819 Salonu'nda sergilenen "Büyük Odalık" adlı eserinden etkilendiği düşünülmektedir. Öyle ki bu sergiden kısa bir süre sonra yaptığı bir desen ile Büyük Odalık arasındaki benzerlik çok açıktır. Her iki eserde de sırtı dönük olan modelin başı izleyiciye doğru çevrilmiş; yatağın üzerine uzanan bacakları ise çapraz bir vaziyette gösterilmiştir. Ancak Delacroix'nın uzanan figürü daha gerçekçi betimlenmiştir.

Delacroix sanat yaşamı boyunca beş adet "odalık" resmi gerçekleştirmiştir. Bunlardan dördü, uzanan Venüs geleneğine uygun biçimde resim düzlemine paralel ya da hafifçe diyagonal bir hat oluşturacak şekilde bir yatak ya da döşek üzerinde uzanan nü betimlemeleridir. Sanatçının kadraja yerleştirdiği bir kaç Doğulu nesne dışında bu betimlemeleri erotik Venüs imgelerinden ayırmak pek mümkün değildir. Sadece 1857'de boyadığı son "Odalık" resminde, yarı giyinik olan figür bir divanda oturmaktadır. Ancak Dalacroix'nın egzotik Doğu ile ilgili en tanınmış eseri, bu odalıklar değil, Cezayirli Kadınlar'dır. 1832'deki Kuzey Afrika seyehatinden iki yıl sonra boyadığı resim, 1834 Salonu'nda sergilenmiş ve belgesel bir gerçeklik duygusuna sahip olduğu için büyük bir ilgi görmüştür. Sanatçı Cezayir'deyken iki gün ziyaret etme fırsatı bulduğu bir haremde onlarca eskiz yapmıştır. Delacroix'nın "Cezayirli Kadınları"ı kurgularken bu eskizlerden yararlandığı bilinmektedir. Güçsav, sanatçının yaptığı eskizleri bir hayli değiştirmiş olsa da ayrıntıların belgesel doğruluğunu korumaya özen gösterdiğini belirtmektedir (2012: 90).

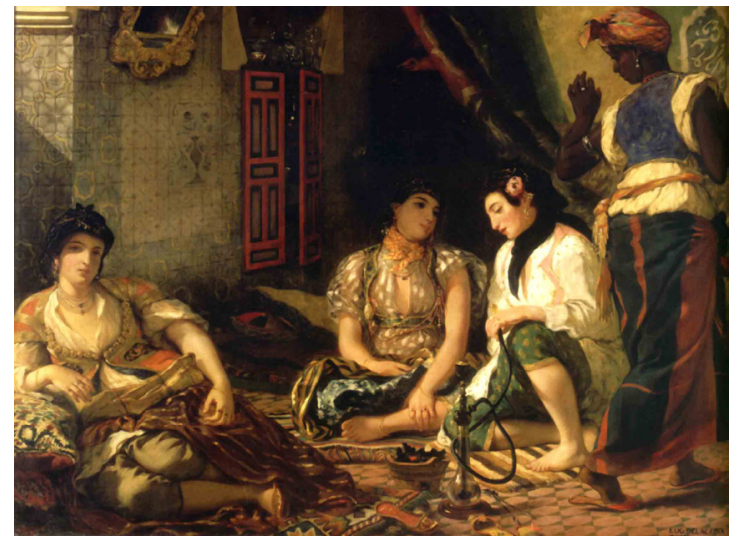

Resim 4. Eugene Delacroix, Cezayirli Kadınlar, 1834, tüyb. 180x229cm

Resim iç mekanda dört kadın figürünün betimlendiği detaylı bir harem sahnesidir. Kompozisyonun solundaki üç figür, neredeyse farklı açılardan poz vermiş tek bir model izlenimi verecek kadar birbirine benzemektedir. Ayakta betimlenen tek figür ise kadrajın sağındaki siyahi hizmetçidir. Arkadan görünen hareket halindeki bu kadın, mekanın dışına çıktığı izlenimi verir. Siyahi kadının üzerindeki kıyafetler, diğer figürlerin kostümlerine nazaran daha sadedir. Hemen yanında biraz geride yerde oturan genç kadın, başına arkadan siyah bir eşarb bağlamış, kulağının üzerine de pembe bir gül yerleştirmiştir. Beyaz uzun gömleğinin üzerine pembe bir yelek geçirmiş, altına ise altın sırmalarla işlenmiş yeşil bir şalvar giymiştir. Profilden betimlenen bu figür yere doğru bakmakta ve elinde nargilenin sapını tutmaktadır. Onun hemen sağında kompozisyonun merkezinde rahat bir tavırla oturan kadın ise cepheden betimlenmiştir. Hafifçe sağa çevirdiği başında siyah bir eşarb bulunmaktadır. Ancak boynuna açık turuncu renkli bir fular bağlamıştır. Şeffaf organze bluzunun üzerinde işlemeli bir yelek bulunmakta, göğsünü bir kaç sıra gerdanlık süslemektedir. Mavi desenli şalvarı da üzerine doladığ çizgili eteği de ağır ve gösterişli kumaşlardan yapılmıştır. Kendi aralarında sohbet eden bu kadınların önünde bir nargile, içinde nargile kömürü bulunan küçük bir sepet ve iki farklı çarık terlik bulunmaktadır. Resmin solunda yerde uzanan kadın figrünün duruşu ise Venüs betimlemelerini anımsatır. Ön planda ve diğerlerinden biraz daha ayrı konumlanmış olan bu figürün üzerindeki gösterişli kıyafetler haremdeki statüsünün diğerlerinden daha yüksek olduğunu düşündürmektedir. Bakışları izleyiciye yönelmiş olan bu genç kadın da diğerleri gibi başına siyah renkli bir eşarp bağlamıştır. Ancak onun eşarbı üzerinde altın yaldızlı zarif süslemeler bulunmaktadır. Kulağını iri küpeler, boynunu ise dört dizi inci kolye süslemektedir. Beyaz gömleğinin üzerine altın yaldızlarla süslenmiş turuncu bir ceket geçirmiş, yeşil 
şalvarının üzerine ise altın yaldızlı şeritleri olan bordo bir kumaş dolamıştır. Sağ bileğinde bir halhal, ayağında ise kırmızı bir çarık terlik bulunmaktadır.

Odanın her tarafına yayılmış olan egzotik nesneler ve birbirine çok yakın konumlanmış kadınlar, neredeyse kadrajın tamamını doldurmaktadır. Sanatçı odanın yan duvarını kadrajın sol tarafında bir diyagonal oluşturacak şekilde konumlandırmış, ancak figürlerin biraz gerisinde sağ taraftan kadraja giren perde ile köşenin görünmesini engellemiştir. Zemindeki seramik karoların üzerinde çeşit çeşit kilim ve halılar ile rengarenk işlemeli yastık ve minderler bulunmaktadır. Tavana kadar seramik karolarla kaplanmış olan yan duvarda bir gömme dolap bulunmaktadır. Dolabın hafifçe aralanmış olan kapağından, rafların üzerinde cam eşyalar olduğu seçilir. Hemen üzerindeki nişin içine de cam eşyalar yerleştirilmiştir. Nişin solunda yüksekçe bir yere eğimli bir ayna asılmıstıı. Aynanın altın yaldızlı gösterişli çerçevesi, bu kalabalık mekanda Batıyı çağrıştıran tek ayrıntıdır. Kadrajın sol üst köşesindeki girintiden mekana süzülen ışık, burada küçük bir pencere olduğunu düşündürmektedir. Pencerenin bu kadar yüksekte bulunması bu loş mekana yoğun bir kapalılık hissi verir ve haremin çağrıştırdığı mahremiyet duygusunu güçlendirir.

Güçsav, Cezayirli Kadınlar sergilendiğinde o zamana dek Avrupalılar için gizemli bir yer olan haremin inandırıcı bir betimi olarak kabul edildiğini ifade etmektedir (2012: 93). Bunun nedeni, gerek figürlerin üzerindeki kostümlerin, gerek odadaki nesnelerin ve gerekse mekanın mimari özelliklerinin ayrıntılı bir biçimde betimlenmiş olmasıdır. Öte yandan sanatçının resme verdiği Cezayirli Kadınlar ismi etnografik bir niteliğe işaret ederken "harem" yerine appartement (daire) ifadesini kullanması, farkl bir okuma talep ettiğini düşündürmektedir. Ancak Güçsav, "Cezayirli Kadınlar"ın bir tanıklık resmi olduğunu düşünmemize engel olan bir kaç hususa dikkati çekmektedir. Neticede Delacroix konuk olduğu haremde bir yabancıdır. Dolayısıyla ait olmadığı bu mekandaki gündelik işleyişe tanıklık etme intimali oldukça azdır. Üstelik kendisine poz veren kadınların islami kuralların katı bir șekilde uygulandığı bir coğrafyada müslüman geleneklerine aykırı bir durum içinde bulunmaları nedeniyle üzerlerinde baskı hissediyor olmaları çok muhtemeldir. Ayrıca Kuzey Afrika gezisine resm bir heyetle birlikte katılan Delacroix'nın Fransa'nın emperyal niyetleri ile ilgili bir eleştirel tutum içinde olmadığı da bilinmektedir. Bu gezi esnasında karşılaştı̆̆ı Doğu'nun gerçekliğinden ne kadar etkilendiğini ifade etse de Delacroix'nın içinde yaşadığı ve kendisini şekillendiren Fransız kültüründen bağımsız olarak Doğu'ya bakabilme ihtimali oldukça zayıftır. Bu ihtilaflı hususlar, "Cezayirli Kadınlar"ın nesnelliğini göreceli hale getirmektedir. Sonuç olarak Delacroix, belgesel görünümlü bu eseri aracilığı ile Avrupalı izleyicilerin zihinlerinde yer eden Doğu imajının gerçekçi bir görünümünü sunmuş olmaktadır (Güçsav, 2012: 97-98).

Gerçekçilik akımının yükselişiyle birlikte Oryantalizm yeniden canlanmış ve Doğu'ya seyahat eden sanatçılar, gittikleri yerlerde uzun zaman geçirmeye başlamışlardır. Buralarda yaptıkları sayısız taslağın yanı sıra belleklerin desteklemek için fotoğraflardan da yararlanmışlardır. Bunun nedeni kısmen Paris salonlarında kabul görebilmek için mimari yapılar ve insan figürlerinin gerçeğe uygun betimlenmesi yönündeki akademik eğilimdir (Needham, 1982: 339)

Ondokuzuncu yüzyılda Fransa'nın en tanınmış ve başarılı ressamlarından biri olan Jean Leon Gerome 1856-1880 yılları arasında defalarca Orta Doğu'ya seyahat etmiş, Filistin, Suriye, Sina, Kahire ve İstanbul'da sayısız taslak çizmis, fotoğraflar çekmiș ve otantik objeler toplamıștır. Sanatçı Fransa'daki atölyesinde bu materyallerden yola çıkarak eserlerini üretmiştir. Gerome'un sayısı beşyüzelliye varan yapıtlarının üçte ikisi oryantal konulardan oluşmaktadır. Siyah-beyaz fotoğraf teknolojisinin yeni gelişmekte olduğu bu dönemde sanatçının fotoğraf bazlı eserleri, gerçeklik yanılsamasını güçlendirmiş; kullandığı canlı renkler fotoğrafla rekabet etmesini kolaylaştırmıştır (Leppert, 2002: 318).

Jean Leon Gerome, 1867 yılında gerçekleştirdiği "Köle Pazarı" adlı eserde

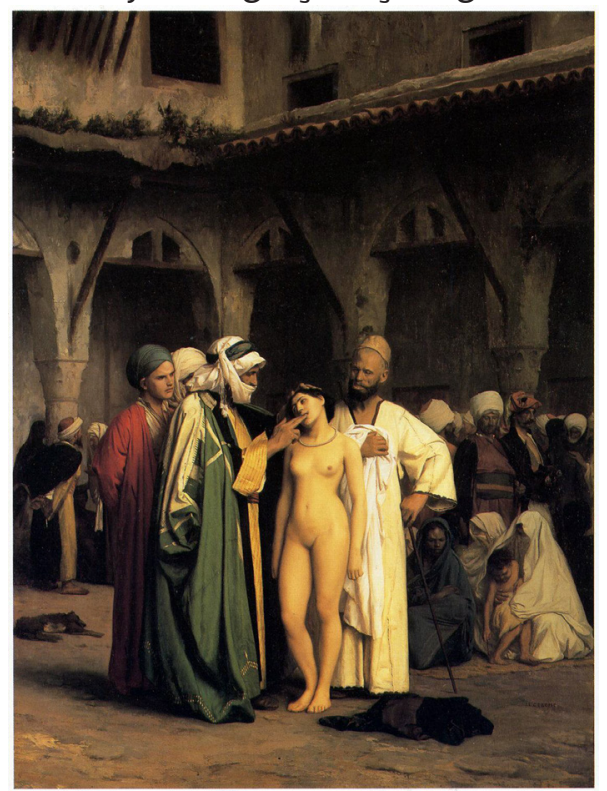

Resim 5. Jean Leon Gerome, Köle Pazarı, I867, tüyb. 63.5 x $84.8 \mathrm{~cm}$. 
Orta Doğu'da bir alış-veriş ritüelini canlandırmaktadır. Resmin merkezinde ayakta duran çıplak kadının beyaz teni, onun Batılı olduğunu imlemektedir. Hemen arkasındaki erkek figürün elinde bulunan beyaz giysi genç kadının bakire olduğunu düşündürür. Başını sola eğmiş olan bu kadının edilgen hali, altın yaldızlarla süslü yeşil bir kostüm giymiş olan Doğulu erkeğin dişlerin muayene etmek için dudaklarına uzanan elinden rahatsızlık duymadığını ima etmektedir. Mekandaki diğer figürlerin tamamı "giyinik"tir. Ancak bedenlerinin büyük bir kısmını örten giysilerinin izin verdiği ölçüde görünen koyu tenleri, Batılı izleyiciye onların "ötekiler" olduğunu düşündürür.

Köle pazarı gibi bir konu, içinde ahlaki iletiler barındırıyor olmakla birlikte kompozisyondaki erotik çağrışımlar resmin ikili okumalara açık bir kurgu olduğunu düşündürmektedir. Bu resimlerde bir yandan Doğulu erkekler miskin ve tembel olarak gösterilirken bir yandan da Ortadoğu, Batılı erkek izleyicinin fantezilerini süsleyen bir hayal diyarı olarak sunulmaktadır. Leppert'a göre bunun nedeni erkeksi siyasal hâkimiyetlerden oluşan Batılı benliğin kültürel üstünlüğünü ilan ve ispat etme çabasıdır (2002: 356).

Ondokuzuncu yüzyılın sonlarına doğru Oryantalist resimler yapılmaya devam edilse de elestirmenler, birbirinin kopyası gibi duran bir resimsellik ve yinelemelerden yakınmaya başlamışlardır. Rosenthall, 1893'de Fransa Oryantalist Ressamlar Derneği'nin kurulmasını, artık yalnızca akademik bir tarz olarak yaşam bulan Oryantalizm'in sonunun gelmesi olarak yorumlamaktadir (Needham, 1982:340).

Ondokuzuncu yüzyıl boyunca Oryantalist bir ilgiyle Doğu'ya yönelen Batı iki boyutlu ve şematik özellikler gösteren Doğu ve İslam sanatını, geçmişi Rönesans'a dayanan natüralist geleneğin içinden algılamayı yeğlemiş ve perspektiften yoksun olduğu için ilkel ve geri olarak değerlendirmiştir (Azman, 2012: 188-189). Ancak 19. yüzyılın ikinci yarısından itibaren Avrupalı sanatçıların ilgisi, egzotik Doğu'dan Doğu sanatına doğru kaymıştır. Bu dönemde Doğulu nesneler, gerçekçi oryantalistlerin yaptığı gibi, sözde Doğulu dekorun bir parçası olarak kullanılmaya devam etse de, Doğu sanatının biçimsel ögeleri yeni bezeme biçimleri yaratmakta kullanılmaya başlamıştır (Güçsav, 2012:160). Eduard Manet, Claude Monet, Camille Pissaro, Alfred Sisley gibi İzlenimci sanatçılar kendilerinden öncekiler gibi Doğu'nun büyüsü ile ilgilenmemişlerdir. Sığ ve katı buldukları realist biçimden uzaklaşarak modern kent yaşamı ve doğayı en basit ve en cazip haliyle gösterebilme çabası, onları Oryantalizmin uzağına itmiştir. Doğu'ya olan ilgileri ise bir kaç istisna dışında Delacroix'e duydukları hayranlığın ötesine geçememiştir (Lemaire, 2001: 256).

1867'de Japonya'nın Dünya Sergisi'ne katılmasıyla birlikte Avrupalılar Ja- pon sanatı, el sanatları ve özellikle de Japon baskılarının inceliği ve eşsiz güzelliği karşısında hayrete düşmüşler ve giderek büyüyen Japon çı|gınlığ Japonizm adında bir sanatsal hareketin başlamasına yol açmıștı. Modern dönemin ilk ustaları Japon sanatını deneyimlerken onun mantığını ve ilkelerini anlamaya çalışmışlar; sembolik olarak gösterilen ve bazen basitçe ortadan kalkan perspektif ile temsil biçimini esnetebileceklerini farketmişlerdir (Lemaire, 2001: 282). Pasifik kültürüne yönelik ilgi ise giderek "köklere dönme" ve daha fazla doğal yaşam arzusuna dönüşmüştür. Eski Mısır heykelleri ve alçak rölyefleri ile siyah Afrika'nın heykel ve masklarının etkisi, diğer egzotik unsurlarla bir araya gelerek Batı sanatının yönünün değişmesinde etkili olmuştur.

Modern sanatın kaynakları arasında Doğu'nun müslüman toplumları da bulunmaktadır Iran minyatürlerinden Türk çinilerine, dokuma ve halılara kadar geniş bir yelpazede bu etkiyi hissetmek mümkündür. Natüralist ifade geleneğinden uzaklaşmak isteyen Batılı sanatçılara yüzey problemlerin aşma konusunda Doğu resminin şematizmi yardımcı olmuş; ön görünüşe dayalı bilimsel perspektiften vazgeçilmesi devrim niteliğinde sonuçlara yol açıštır (Azman, 2012: 188-189). 1900'lerin erken tarihlerinden itibaren Paris ve Münih gibi kentlerde gerçekleştirilen İslam Sanatları sergileri, Avrupalı sanatçıların Doğu estetiğini keşfetmeleri için fırsatlar sunmuştur (Lemaire, 2001: 287). Alman sanat tarihçi Julius Lessing, 1878'de Paris'te düzenlenen Dünya Fuarı'ndan bahsederken “...her ne zaman Avrupalı hayal gücü körelmeye başlasa ve Avrupa sanatı gerileme eğiliminde olsa Doğu sanatının Batılı sanatçının fantazisini beslemek için bütün tazeliği ile ortaya çıktığııı" dile getirmektedir (Güçsav, 2012:160). Gerçekten de Avrupa resminin tıkandığı noktada sömürge ülkelerin sanatı, Batılılara geniş ölçüde ilham kaynağı olmuştur. Ancak Modern dönem sanatçıları arasındaki yaygın eğilim, Doğu sanatını Batı sanatı içinde eritme anlayışıdır (Shiner, 2004: 402-408).

Fovların en ünlü üyesi Henry Matisse, pek çok modern sanatçı gibi Doğu ve İslam sanatlarına özellikle de minyatür, çini ve halı dokumalara ilgi duymaktadır. 1906 ve 1912 yılları arasında Cezayir ve Fas'a yaptığı geziler Matisse'e ilham vermiş; Doğu sanatı ve estetiği, soyut dekoratif bir mekân anlayışı geliştirmesinde etkili olmuştur (Altıntaş, 2014: 75). Ancak, bu süreçte ürettiği eserler, yaşam deneyimleri sonucu edindiği izlenimleri yansıtır. Matisse, sanatı için yeni bir yöntem arayışında olmasına rağmen Batı ı resim geleneği ile bağlarını tamamen koparmamışıı. Zaten bu süreçteki amacı efsanevi bir Doğu yaratmak değildir. Batı sanatını Doğululaştırmak yerine Doğu'dan aldığı fikirleri Batılılaştırma eğilimindedir (Lemaire, 2001: 298). Batı sanatı, perspektif ilkeleri, ışık ve renk ilişkileri kullanılarak oluştu- 
rulan hacim ve derinlik yanılsaması üzerine yapılandırılmıştır. Oysaki İslam sanatı üç boyut etkisini yadsımaktadır. Bu iki gelenek arasındaki intilaf, Matisse'in resimlerinde figür ve zemin arasındaki ihtilafı beslemiştir. Sanatçı 1910 'lu yıllarda İslam minyatürlerinin ilkelerini uygulayarak gerçekleştirdiği resimlerinde bezemelerle süslenmiş mekânda betimlediği figürleri arka planla kaynaştırmaya yeltenir. Ancak giysilerle örttüğü insan bedenlerinin oylumlarını gizlemek, üç boyutlu figür ve iki boyutlu resim düzlemi arasındaki ihtilafı gidermeye yeterli olmaz (Güçsav, 2012: 163-164).

Matisse, 1920'li yıllarda Odalık konulu yaklaşık elli adet resim üretmiştir. Sanatçının Kuzey Afrika gezilerinden yaklaşık on yıl sonra başladığı bu seri, Ondokuzuncu yüzyıl Oryantalist resim geleneğinin bir devamı olarak düşünülebilir. Bu gelenek içerisinde çok iyi tanımlanmış olan odalık figürü, onun resimlerinde merkezi bir motife dönüșmüstür. Ingres, Delacroix ve Gerom'un eserlerinden aşina olduğumuz Doğulu nesneler de Matisse'in resimlerinde tekrar tekrar kullanılmıştır. Sanatçının yirminci yüzyılın başlarında artık önemini yitirmiş ve birbirinin kopyası haline gelmiş olan oryantalist resimlere yönelmesi ve bunların başat figürü olan odalık gibi bir konuyu tekrar tekrar resimlemesi hayli ilgi çekicidir. Oysaki Matisse'in resimlerinde hayatın içindeki gerçekliğe koşut yeni bir gerçeklik yaratmak istediği bilinmektedir. Fovist döneminden itibaren en temel meselesi resim yüzeyinde düzlük ve derinlik arasındaki ihtilafı çözümlemek olan Matisse, bu doğrultuda hem biçimi deforme etmeye yönelmiş, hem stilize biçimler kullanmış, hem de renk ilişkilerini görsel algıyı zorlayacak şekilde kullanmayı denemiştir. Konu ise onun için bir araç olmaktan öteye gitmemiştir.

Matisse, "Odalık" serisinde düzlük ve derinlik arasındaki ihtilafı gidermek için İslam sanatının bezeme mantığını kullanmaya yönelir. Çünkü İslam estetiğinde uzam, yüzey tarafından belirlenmekte; yüzey ise motif tekrarı ile elde edilen bezemelerden oluşmaktadır. Sanatçı ton geçişleri kullanmadığı renkli yüzeylerde motif tekrarlarından oluşan bezemeler aracılığı ile derinlik etkisi oluşturma çabasına girer. Çoğunlukla çıplak ya da yarı çıplak betimlenmiş olan figürlerin tenindeki tonalite uygulamasının neden olduğu hacim etkilerini bertaraf etmek için ise kalın konturler kullanır. Figür ve zemin arasında uzlașıma varma çabası bu resimlerde Doğu estetiği ile Cezanne etkilerini yan yana getirmiştir. Ancak İslam sanatlarının etkisi arttıkça konu ve içerik önemini yitirir. Bildiğimiz anlamda bir "nü" olmaktan çıkan "odalık" figürü, giderek merkezi bir motife dönüşür ve kompozisyonun diğer elemanlarını bir arada tutan itici bir kuvvet gibi görünmeye başlar (Güçsav, 2012:167).

Matisse'in Doğu sanatı ile kurduğu ilişkinin merkezinde "tekrar" ilkesi bulunmaktadır. Tekrar ederek bezemeyi oluşturan motifler, sıradüzensel anlamlarını kaybedip merkezi önemini yitirirken içleri de boşalmaktadır. Artık her bir motif yüzeyi oluşturan bezemenin eşit öneme sahip bir bileşenidir. Ancak Matisse'in resimlerindeki bezeme mantığı yüzey örüntüsü ile sınırlı değildir. Sanatçının "Odalık" serisindeki tüm eserlerine bir bütün olarak bakıldığında odalık figürlerinin adeta birbirinden türediği; pirinç semaver, ahşap sehpa, çiçek vazosu, odalığın üzerine uzandığı şilte ve başını koyduğu yastık gibi eşyaların ise tekrar tekrar kullanıldığı görülür. Matisse İslam sanatının bezeme mantığını daha da ileriye taşımış ve gündelik eşya ve insan figürlerini birer motife dönüştürmüştür. Böylece Oryantalist gelenek içinde çok iyi tanımlanmış olan odalık figürü de Doğulu nesneler de anlamlarını yitirmiş ve içerikten yoksun birer bezeme unsuru haline gelmişlerdir (Güçsav, 2012:168).

Sanatçının 1925 ve 1927 yıllarına tarihlenen bes adet Odalık resminin her

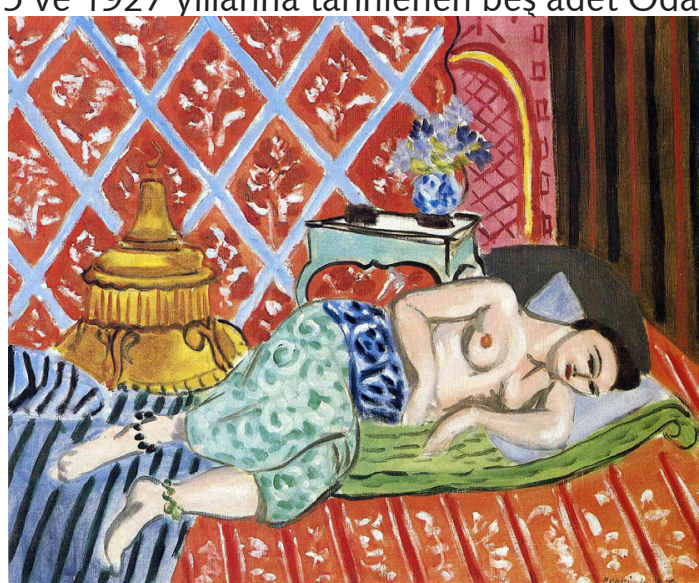

Resim 6. Henry Matisse, Yeșil Şalvarlı Mavi Kuşaklı Uzanan Odalı, 1927, tüyb, $98 \times 130 \mathrm{~cm}$.

birinde resim düzlemine paralel bir döşek üzerine uzanmış yarı çıplak bir figür betimlenmiştir. Hepsi de birbirinden türemiş gibi görünen bu resimlerde sanatçı aynı şablonu kullanmışıtır. Yatay düzlemde ikiye ayrılan bu resimlerin üst kısmı arka planı, alt kısmı ise zemini oluşturmaktadır. Resim düzleminin alt yarısına yerleștirilen nülerle arka plan arasında, pirinç bir semaver ile -üzerinde içinde çiçekler olan seramik bir vazo ve kapaklı bir kutu olan- ahşap bir sehpa bulunmaktadır. Arka plan ise dikey düzlemde üç yüzeye ayrılmıştır. Bu yüzeylerin her biri farklı motiflerle bezenmiştir. Kadrajın solundaki en geniş olan yüzey dörtgenlere bölünmüş ve her birinin merkezine çiçek motifi yerleștirilmiștir. Kırmızı zemin üzerindeki bezemelerde beyaz ve mavi rengin kullanıldığı bu yüzeyin sağ kenarındaki 
oylumlar kalın konturlerle vurgulanmıştır. Bu vurgu arka plandaki yüzeyler arasında ön arka ilişkisi olduğunu göstermektedir. Arka planın ortasındaki bölümde dikkati çeken kemer motifinin üçte birlik kısmı, soldaki yüzeyin arkasına girdiği için görülmemektedir. Kemerin içi kırmızı çizgilerle dörtgenlere bölünmüş, dışında ise irili ufaklı geometrik desenler kullanılmıştır. Beş Odalık resminde de ufak tefek değişikliklerle tekrarlanan bu yüzey sanatçının ... tarihinde boyadığı Mağribi Paravanı adlı eserde kullandığı paravanı anımsatmaktadır. Dolayısıyla bu bölümün bir paravan, sağındaki yüzeyin ise paravanın üzerine örtülmüş bir kumaş olduğu sonucu çıkartılabilir. Kırmızı, siyah ve yeşil renkli dikey şeritlerden oluşan en sağdaki tanımsız yüzey ise biraz daha geride algılanmaktadır. Ön planı oluşturan alt kısımdaki bezemeler, belli belirsiz bir perspektifle zeminin geriye doğru gitmesine katkı sağlamaktadır. Bu bölümde yatağın ya da zeminin üzerine serilmiş bir şilte ve üzerindeki yastıklara başını dayayıp uzanmış olan bir figür betimlenmiştir.
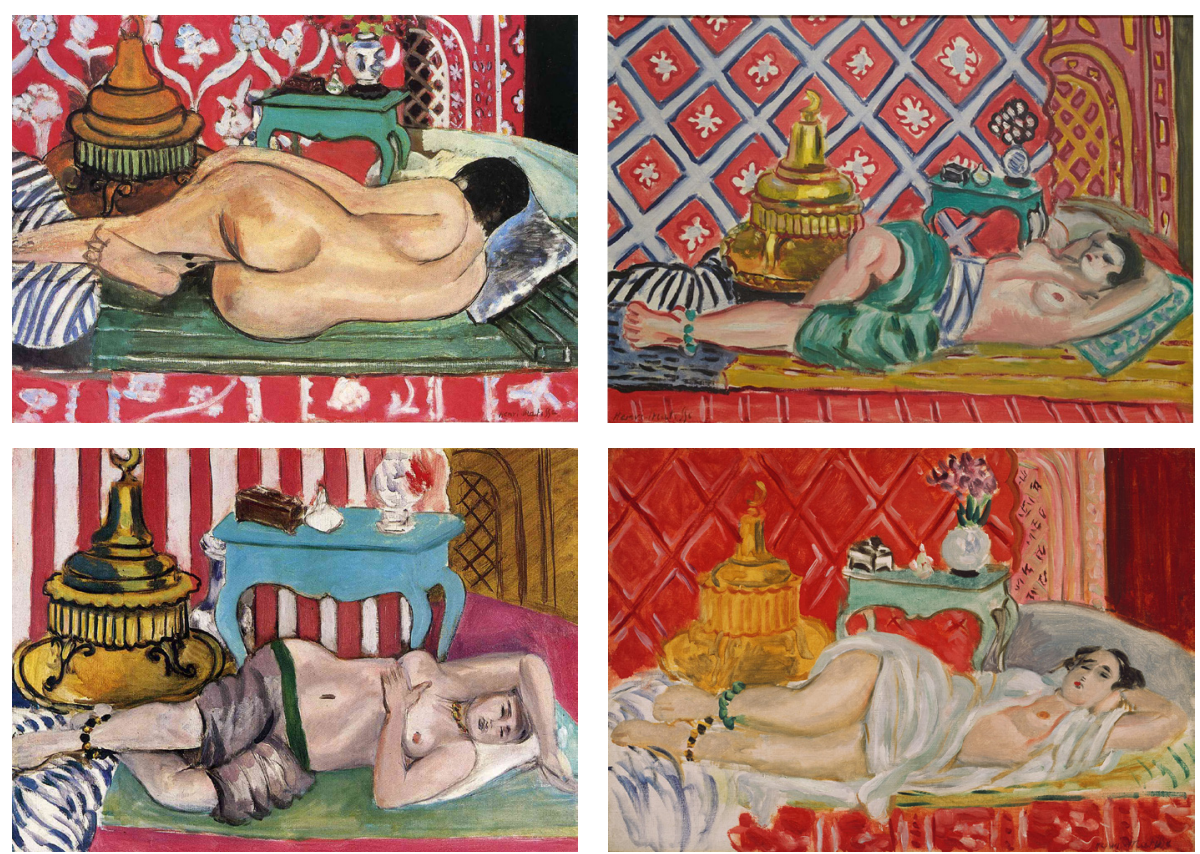

Resim 7. Henry Matisse, Arkadan Görünen Uzanan Odalık, 1927, tüyb, 66x92cm. (Sol Üstte)

Resim 8. Henry Matisse, Uzanan Odalık, 1926, tüyb, 38.4x54.9cm. (Sağ Üstte) Resim 9. Henry Matisse, Yeşil Kuşaklı Odalık, 1926-27, tüyb, 50.8x64.8cm. (Sol Altta) Resim 10. Henry Matisse, Kırmızı Armonili Uzanan Odalık, 1927, tüyb, $38.4 \times 55 \mathrm{~cm}$. (Să̆ Altta)
Her birinin ayak bileklerinde halhal olan bu figürler, bir yandan Ingres'ın odalıklarını çağrıştırır bir yandan da Venüs temsilleri ile bağlantı kurar. Matisse'in odalıklarından üçünün üzerinde göbeği açıkta bırakan ve dizlere kadar uzanan şalvar bulunmaktadır. Arkadan betimlenen odalık bu beşlinin içinde tamamıyla çıplak olan tek figürdür. Beşinci odalığın üzeri ise beyaz bir kumaşla kısmen örtülmüştür. Hepsinin ayaklarının altında koyu mavi renkli çizgileri olan beyaz bir çarşaf bulunmaktadır. İzleyici ile göz teması kurmayan bu içe kapalı odalıklar, Monet'nin Rouen Katedrali serisini düşündürür. Matisse, yatağa uzanan modelinin uyku halindeyken değişen hareketlerini betimlemiş gibidir.

Fovist döneminden itibaren sıcak-soğuk ve kontrast renk ilişkilerini resim yüzeyinin düzlüğünü vurgulamak için kullanan Matisse, aynı yöntemleri bu seride de uygulamakla birlikte ikili karşıtıkları birbiri içinde eritmeyi denemiştir. Natüralist geleneğin yüzyıllar içinde olgunlaştırdığı derinlik ve form yanılsamasını, üç boyut etkisini yadsıyan İslam estetiğinin ilkelerini kullanarak oluşturmaya çalışmıştır. Odalık resimlerinde ton geçişleri ya da açık-koyu ilişkileri kullanılmamasına rağmen bezemeli yüzeyleri oluşturan motifler, uzam ya da oylum etkisi verecek şekilde organize edilmiștir. Tonalitenin neden olduğu hacim etkisi ise yalnızca odalıkların giysilerden açıkta kalan bedenlerinde hissedilmektedir. Matisse hacim etkisini yok ederek figürle mekânı birbiri içinde eritmek için bedenin etrafını kalın konturlerle çevrelemeyi denemiştir. Böylece yüzeyle kaynaşan figür, Batı sanatında yüzyıllardan beri koruduğu öncelikli konumunu yitirmiştir. Matisse, tüm yüzeyin bezemelerle kaplı olduğu bu resimlerin bütünlüğü içerisinde nesneler gibi figürleri de birer motife dönüştürmüştür.

Fovizmin öncüsü ve Modern sanatın en önemli ustalarından biri olan Matisse'in artık önemini yitirmiş ve sıradanlaşmış olan oryantalist resim geleneği içindeki bir konuya yönelmiş olması hayli ilgi çekicidir. Öte yandan Matisse'in resimlerindeki odalıklar Ingres, Delacroix ve Gerome gibi oryantalist sanatçıların harem sahnelerindeki kadınlardan oldukça farklıdır. Bulundukları mekânın içinde adeta kaybolan bu kadınlar erotik çağrışımlar yapmaktan oldukça uzaktır. Oryantalistlerin resimlerinde Doğulu erkeklerin cinsel haz nesneleri olarak gösterilen; dolayısıyla bir yönüyle Batının emperyalist emellerine ahlaki gerekçe oluşturan başka bir yönüyle de bu emelleri süsleyen egzotik güzellerin devri artık kapanmıştır. Çünkü 20 yüzyılın erken tarihlerinden itibaren Batı, içine kapanmış ve kendi medeniyetini sorgulamaya başlamıştır. Bu süreçte yeni ifade arayışlarına giren Avrupalı sanatçılar için Batı dışı toplumların kültür ve sanat formları bir çıkış noktası olmuştur. Yüzyıllar içinde geliştirdikleri natüralist sanat geleneğini aşabilmek için, Doğu'nun biçim anlayışını Batı sanatı içinde eriterek ve ken- 
dilerine mal etmişlerdir. Modern dönem ustalarının resimlerinde "Doğu" artık içeriği değil biçimi belirleyen bir unsur olarak karşımıza çıkar. Matisse de Doğu sanatının yöntemlerini kullanarak "odalık" imgesini biçimsel bir ögeye dönüştürmüş ve içini boşaltarak anlamını feshetmiştir.

20 yüzyıl Batı sanatında doğu toplumlarına yönelik "oryantalist" ilginin kaybolması Matisse'in "Odalık" resimleri ile görünür hale gelmiştir. Ancak ironik bir şekilde "oryantalist" söylem bu süreçte Batı dışı toplumlar tarafından devralınmıstır. 18. yüzyıldan itibaren sömürgelestirilen ya da Batı karşısında güç kaybederek gerileyen Doğu toplumları, Batının merkezi konumu kabullenmiş ve kendilerini Batı üzerinden tanımlamaya başlamışlardır. Bu toplumlarda modernleşme ile batılılaşma bir tutulmuş ve toplumsal kurumlar yenilenirken Batı örnek alınmıştır. Batı medeniyetinin üstünlüğg̈ konusundaki gizli mutabakat ise yerel kültürün ötekileştirilmesine ve yerel konulara içselleştirilmiş bir oryantalizmin perspektifinden bakılmasına neden olmuştur.

\section{Kaynakça}

Altıntaş, Osman, "Matisse'in Eserlerinde Oryantalizm", ídil Dergisi 3.II.2014

Azman, Ayşe, “Oryantalistlerin İstanbul'undan Bienalin İstanbul'una", Sosyoloji Dergisi, 3. Dizi, 24. Sayı, 20I2/I

Çırakman, Aslı, "Oryantalizmin Doğusu ve Oryantalist Bilgi”, Toplumsal Tarih Dergisi, İstanbul 2003

Denny, Walter B. (1983), “Orientalism In European Art*”. The Muslim World, 73: 262277. doi: /0.1/II/j. I478-19/3.1983.tb03268.x

Germaner, Semra; Inankur, Zeynep, Oryantalizm ve Türkiye, Türk Kültürüne Hizmet Vakfı Yayınları, İstanbul, 1989

Güçsav, Gonca, Odalık, Görünmeyeni Sergilemek, (çev. Evren Yılmaz), Yapı Kredi Yayınları, istanbul, 2012

Keyman, Fuat; Mutman, Mahmut; Yeğenoğlu, Meyda, Oryantalizm, Hegemonya ve Kültürel Fark içinde Oryantalizmin Gölgesi Altında: Batı'ya Karşı İslam, Iletişim Yayınları, İstanbul, 1999

Lemaire, Gerard-Georges, The Orient in Western Art, Könemann, Köln, 200 I

Leppert, Richard, Sanatta Anlamın Görüntüsü , Ayrıntı Yayınları, İstanbul, 2002

Needham, Gerald, “Orientalism in France”, Sanat Dergisi, Sayı 42, Bölüm 4, 1982

Said, Edward. "Oryantalizm (Doğubilim) Sömürgeciliğin Keşif Kolu”, (çev. Nezih

Uzel), İran Yayıncılık, İstanbul, 1998

Shiner, Larry, Sanatın İcadı Bir Kültür Tarihi, (çev. İsmail Türkmen), Ayrıntı Yayınları, İstanbul, 2004

Uluç, Güliz; Soydan, Murat, "Said, Oryantalizm, Resim ve Sinemanın Kesișme Noktasında Harem Suare" Bilig, Yaz, s:42: 35-53, 2007 


\section{Görsel Kaynakları}

Resim I: Jean Dominique Ingres, Büyük Odalık, I814, tüyb. $162 \times 91 \mathrm{~cm}$.

https://commons.wikimedia.org/wiki/File:Jean_Auguste_Dominique_Ingres,_La_ Grande_Odalisque,_18/4.jpg

Resim 2: Jean Auguste Dominique Ingres, Köle ve Odalık, I842, tüyb, $76 \times 105 \mathrm{~cm}$.

https://www.tarihnotlari.com/wp-content/uploads/2013/04/odalisque-withfemale-slave- /842-by-jean-auguste-dominique-ingres.jpg

Resim 3: Jean Auguste Dominique Ingres, Türk Hamamı, I862, tüyb, çap: $108 \mathrm{~cm}$.

https://www.thinglink.com/scene/726503934453088257

Resim 4: Eugene Delacroix, Cezayirli Kadınlar, 1834, tüyb. 180x229cm.

http://mironovacolor.org/articles/style_evolution/romantism.html

Resim 5: Jean Leon Gerome, Köle Pazarı, I867, tüyb. 63.5 x $84.8 \mathrm{~cm}$.

http://allart.biz/up/photos/album/G/Jean_Leon_Gerome/jean_leon_gerome_64_ slave_market.jpg

Resim 6: Henry Matisse, Yeşil Şalvarlı Mavi Kuşaklı Uzanan Odalık, 1927, tüyb, $98 \times 130 \mathrm{~cm}$

https://www.baskiloji.com/kanvas-tablo/68806/a-nude-lying-on-her-back-1927\#

Resim 7: Henry Matisse, Arkadan Görünen Uzanan Odalık, 1927, tüyb, 66x92cm. https://www.baskiloji.com/kanvas-tablo/69/3I/reclining-nude-back-1927\#

Resim 8: Henry Matisse, Uzanan Odalık, 1926, tüyb, 38.4x54.9cm.

http://www.artribune.com/wp-content/uploads/2017/04/Henri-MatisseReclining-Odalisque-1926.jpg

Resim 9: Henry Matisse, Yeşil Kuşaklı Odalık, 1926-27, tüyb, 50.8x64.8cm.

https://www.baskiloji.com/kanvas-tablo/688/2/odalisque-with-green-scarf\#

Resim I0: Henry Matisse, Kırmızı Armonili Uzanan Odalık, 1927, tüyb, 38.4×55cm.

https://www.metmuseum.org/toah/works-of-art/1999.363.44 